\title{
Om Dannelsen af den provisoriske Regering i Kiel Natten mellem den 23. og 24. Marts 1848.
}

\section{En kildekritisk Undersegelse.}

Af Holger Hjelholt.").

I Dagbrækningen den 24. Marts 1848 oplæste Wilh el m B e s e l e r fra et Vindue paa Raadhuset i Kiel for en paa Torvet talrig forsamlet Menneskeskare en Proklamation, forfattet af den i Nattens Løb dannede provisoriske Regering, for hvilken han stod i Spidsen. IProklamationens Ordlyd var følgende:

"Medborgere!

Vor Hertug er ved en Folkebevægelse i København blevet tvungen til at afskedige sine hidtidige Raadgivere og til at indtage en fjendtlig Holdning over for Hertugdømmerne.

Landsherrens Vilje er ikke mere fri, og Landet er uden Regering.

Vi vil ikke taale, at tysk Land bliver givet til Pris for de Danskes Rovlyst. Store Farer kræver store Beslutninger; der behøves en styrende Myndighed til at forsvare Grænsen og opretholde Ordenen.

Idet vi bøjer os for den paatrængende Nødvendighed og føler os stærke ved den os hidtil udviste Tillid har vi, følgende det Kald, der er udgaaet til os, foreløbig overtaget Ledelsen af Regeringen, som vi vil fore $i$ vor Arvehertugs Navn og til Op. retholdelse af Landets og hans Rettigheder.

Vi vil uopholdelig sammenkalde den forenede Stænderforsamling, og saa snart som Landsherren igen er fri, eller Stæn-

*) Den falgende Fremistilling er holdt som Forelasning paa Købonhavns Universitet don 2. November 1936 under den Konkurrence om Professoratet i Historie, som da fandt sted. Den var Besvarelse paa Opgaven: Fremlaggelse af it kildekritisk Problem efter eget Valg, til hvis Udarbejdelse der var sat en Frist af $\tau$ Dggn. 
derforsamlingen har overdraget Ledelsen af Landets Anliggender til andre, vil vi give Magten tilbage.

Vi vil med al Kraft slutte os til Tysklands Enheds- og Frihedsbestræbelser.

Vi opforder alle Landets velsindede Indbyggere til at forene sig med os. Lad os ved Fasthed og Orden give det tyske Fædreland et værdigt Vidnesbyrd om den patriotiske Aand, der opfylder Slesvig-Holstens Befolkning.

Den fraværende Advokat B r e m er vil blive opfordret til at tiltræde den provisoriske Regering.

Kiel, den 24. Marts 1848.

Den provisoriske Regering:

Beseler. Friedrich, Prinz zu Schleswig-Holstein.
F. Reventlou.
M. T. Schmidt. «

Dannelsen af den provisoriske Regering og Udstedelsen af dens Proklamation fremkaldte umiddelbart Treaarskrigen og maa siges at indvarsle Opløsningen af de Baand, der gennem fire Aarhundreder havde knyttet Holsten til Danmark. Det er rlerfor en ret nærliggende Opgave for dansk Historieforskning at undersøge de nærmere Omstændigheder ved den provisoriske Regerings Opstaaen, og en saadan Undersøgelse vil desuden efter min Mening have ikke ringe metodisk Interesse. Inden jeg imidlertid gaar over til at skildre det paagældende Kildenateriale, er der et Punkt i Proklamationen, som jeg lige med et Par' Ord skal omtale.

De fire Herrer, der har undertegnet Proklamationen, taler i denne om den Tillid, der hidtil er vist dem, og om, at de foreløbig har overtaget Regeringens Ledelse, følgende det Kald, der var udgaaet til dem. Naar man sammenholder disse Udtalelses med de senere i Proklamationen om, at de uopholdelig vil sammenkalde "den forenede Stænderforsamling " og give Magten tilbage, saafremt denne onsker den overdraget til andre, vil det ses, at Udtalelserne maa sigte til, hvad der skete i Rendsborg den 18. Marts. Denne Dag mødtes som bekendt her Deputerede fra den slesvigske og fra den holstenske Stænderforsamling - det er dette, der kaldes "den forenede Stænderforsam- 
ling«, skønt demnes Eksistens var ganske ulovlig. De Deputerede - næppe uden Paavirkning fra en samtidig holdt Folkeforsamling - besluttede Afsendelsen af en Deputation paa 5 Mand til Kongen, der af demne skulde kræve Opfyldelsen af en nærmere formuleret Række slesvig-holstenske Krav: Foreningen af de 2 Stænderforsamlinger til een for at raadslaa om en "slesvig-holstensk « Forfatning, Folkevæbning, Presse- og Forsamlingsfrihed og Afskedigelse af Regeringspræsident Scheel i Slesvig. De 5 Afsendinge var Regeringsraad Engel, Godsejer Neergaard, Redaktøren af Kieler Correspondenzblatt Th. Olshausen og Advokaterne Gülich og Claussen. De tilhørte alle Veustrefraktionerne. Inden de Stænderdeputerede drog hver til sit, var der blevet nedsat et Tremandsudvalg, bestaaende af Beseler, der havde været Præsident for den slesvigske Stænderforsamling, Grev Reventlou-Preetz, Foreren for den holstenske Opposition, samt Advokat Bargum. Dette Udvalg fik den Opgave at sammenkalde Stænderne paa ny, naar det gjordes fornødent. Det er hertil, at Proklamationens Udtalelse: "følgende det Kald, der var udgaaet til os", maa sigte, men da Bargum ikke optoges $i$ den provisoriske Regering, medens denne foruden Beseler og Reventlou ved sin Dannelse talte ogsaa Prinsen af Nør og Købmand M. T. Schmidt i Kiel, svarede Udtalelsen for saa vidt ikke til de faktiske Forhold.

Den Deputation, som Mødet i Rendsborg havde besluttet at sende til København, afrejste først fra Kiel den 21. Marts og kom til København Dagen efter. Kongens Svar paa dens Krav fik den den 24., og om Morgenen den 26. var Afsendingene atter tilbage i Kiel. Det følger af disse Datoer, at Svaret til Deputationen ingen Interesse har for Spørgsmaalet om den provisoriske Regerings Dannelse.

Hvad der foregik i Kiel i Natten mellem den 23. og 24. Marts, var unægtelig en "Pressesensation", og skønt den daværende Presse i mange Henseender saa vist har et andet Ansigt end Pressen i Dag, søgte den saa godt som muligt at opfylde Læsernes Krav. Olshausens Organ "Correspondenz-Blatt" udsendte den 24. Marts et "Extra-Blatt« paa 2 Sider, indeholdende en Skildring af det passerede under Titlen: Die Unabhängig- 
keit Schleswig-Holsteins ist proclamirt. Til denne Skildrings Kildeværdi skal jeg senere komme tilbage. Det i Hertugdømmerne meget udbredte Blad "Altonaer Mercur" - spogefuldt kaldet Tante Mercur - der udkom hver Aften Kl. 6,30 (undtagen Søndag), kunde i sit sædvanlige Nummer for den 24. bringe Efterretningen om Begivenheden. Derimod maatte "Gemeinnütziges unterhaltendes Itzehoer Wochenblatt" den 24. udsende hele 2 Ekstraudgaver, forst et "Extra-Blatt» for at fortælle om Revolutionerne i Berlin og Wien, saa samme Dag Kl. 12 et "Beilage zum Extrablatt" for at fortælle om Omvæltningerne i København og Kiel. Den sidste Udgave kan - bortset fra Typerne - vel siges at svare til vore Avisers Løbesedler.

Af Avisskildringer skal jeg holde mig til de tre nu nævnte, og jeg skal derefter omtale en Række Skrifter og Optegnelser fra Mænd, der selv var virksomme ved den provisoriske Regerings Dannelse. Jeg nævner de paagældende Skrifter i den Tidsfølge, i hvilken de er udkomne. Jeg vil dog her gøre den Bemærkning, at jeg m. H. t. disse Skrifter ikke tør gøre Krav paa absolut Fuldstændighed, selv om jeg vil mene og haabe, at jeg har medtaget alle vigtigere. For os, der sysler med nyere Historie, er Spørgsmaalet om Fuldstændighed i Kildebenyttelsen noget af en Achilleshæl, og desuden trues vi stedse af - cller kan glædes ved -, at der fra Arkiver eller private Samlinger kan fremdrages hidtil ukendt Stof, der kan forrykke eller supplere vor hidtidige Viden.

I Foraaret 1850 udkom Skriftet $" D$ i e Herzogth ümer Schleswig-Holstein und das Königreich Dänemark. Aktenmässige Geschichteder dänischen Politikseit dem Jahre 1806 . Skriftet havde to Forfattere: Professor Johann Gustav Droysen og den kendte Pennefører for Augustenborgerne Karl Samwer. Da Droysen - sammen med Dr. Ahlmann - straks den 24. udnævntes til den provisoriske Regerings Sekretær, og det hævdes, at han har skrevet dens Proklamation, maa han sikkert siges at have gode Forudsætninger for at kende det, som han skildrede. Det samme galder Samwer, der selv var virksom ved Begivenhelen, og som stod i nær Forbindelse med Augustenborgerne. Om 
Skriftets Opstaaen faar vi en Række Oplysninger i de Breve, der herom veksledes mellem Droysen og Samwer, og som er trykte i det i 1929 udkomne 1. Bd. af Johann Gustav Droysens Briefwechsel, udgivet af .Rudolf Hübner. Det fremgaar af disse Breve, at 1. Bog er skrevet af Samwer, de to følgende af Droysen, men at de dog har staaet $i$ et vist Samarbejde, og at de bl. a. har faaet Oplysninger af Augustenborgerne. Det fremgaar endvidere af Brevene, at Skriftet er et Tendensskrift, bestemt til at virke som en Slags "Memorandum" til de kommende Fredsforhandlinger mellem Danmark og Tyskland. Denne Tendens har, som jeg senere skal vise, ogsaa sat sit Præg paa Skildringen af Begivenhederne mellem den 23. og 24. Marts. Naar Droysen i et af Brevene til Samwer betoner, at der ikke maa være positive Urigtigheder i Skriftet, kunde han altsaa for saa vidt hævde, at det intet indeholdt uden "Sandhed", men han kunde ingenlunde tilføje, at det indeholdt »den hele Sandhed". I det Kamphumør, hvori han var, skrev han under Bogens Udarbejdelse den 11. Januar 1850 til Samwer: "Es ist allmählich ein wundervolles Material beieinander, und man sieht der dänischen Staatsmännerei und Schandpolitik bis in die Gedärme. Schon heut freue ich mich auf die Lügen, die man gegenschreiben wird."

Godt 10 Aar senere - i 1861 - udgav et af selve den provisoriske Regerings Medlemmer, nemlig Prinsen af Nør, sine Erindringer fra det bevægede Tidsrum: "A u f ze ichnungen des Prinzen Friedrich von Schleswig-HolsteinNoeraus den Jahren 1848 bis 1850 ." Han meddeler $i$ Forordet, at Bogen er en Omarbejdelse af nogle Optegnelser, som han nedskrev i 1849 og 1850, og han lægger ikke Skjul paa, at Skriftet skal virke som et Forsvarsskrift, tillige betoner han stærkt sin Upartiskhed og Sandhedskærlighed. Erindringer plejer som Regel at overvurdere Forfatterens Betydning og Virksomhed, og dette i stedse højere Grad, jo mere imponerende vedkommende selv finder sig. Som bekendt hørte Prinsen af Nør ikke til dem, der undervurderede sig selv. Med Hensyn til hans Skildring skal desuden bemærkes, at hans arrogante, fyrstelige Natur ikke havde meget tilfælles med folkelige, revolu- 
tionære Bevægelser. Trods disse Fejlkilder, som maa tages $\mathbf{i}$ Betragtuing, maa Optegnelserne, stammende fra et Øjenvidne, sikkert tillægges betydelig Kildeværdi.

Fra et ganske modsat Standpunkt er Ot to Focks S leswig-Holsteinische Erinnerungen besonders a us den Jahren 1848-1851, der udkom 1863, skrevne. Fock var i Revolutionsaaret Docent i Kiel, han hørte til det slesvig-holstenske Fremskridtsparti og var blandt dem, der elektriceredes af Februar-Revolutionen i Paris. Han ønsker ikke at skjule, hvordan man drev Vaabenovelser i Kiel forud for Oprøret, og han lægger ingen Vægt paa at vise, at man i Holsten var rolige, langsomme og lovlydige og kun dreves til Modstand ved danske Angreb og Overgreb. Han kritiserer stærkt Prinsen af Nørs Skildring af Begivenhederne Natten mellem 23. og 24. Marts og giver selv en udførlig Fremstilling af disse, om end han et Par Gange indskyder: "Wenn mich meine Erinnerung nicht trübt«. Han bemærker desuden, at han har sammenlignet sine Erindringer med andres Beretninger, der deltog i Begivenhederne. Herved gjorde han ganske vist den Erfaring, hvor vanskeligt det var ved sammensatte Begivenheder at konstatere den nøjagtige Tidsfølge af disse, særlig naar der var hengaaet længere Tid siden Begivenhederne. Det er en Erfaring, som vistnok flere end Otto Fock har gjort.

I 50-Aaret for Revolutionen udgav Karl Samwers Son nogle Optegnelser fra sin Faders Papirer under Titlen: Die Erhebung Schleswig-Holsteins vom 24. März 1848 . Det lille Skrift indeholder 2 Skildringer, som Samwer til forskellig Tid har nedskrevet om Begivenhederne: den første skal være skrevet omkring 1852, den sidste derimod i 1878 som en Del af de Livserindringer, han da affattede. Den sidste Skildring er mere summarisk, henviser til den første, men indeholder dog ogsaa nye Meddelelser. Samwers Standpunkt præges som før nævnt af hans Forbindelse med Augustenborgerne.

Endelig skal jeg nævne, at der i o t t o B es e le rs 1914 udgivne Biografi af hans Fader Wilhelm Hartwig Besel e r er gengivet et Brev, som denne den 23 . Marts 1873 skrev til sin Broder, og hvori han mindes, hvad der skete samme Dag 
for 25 Aar tilbage. Wilhelm Beseler er for ovrigt selv, men særdeles kortfattet, kommet ind paa Begivenhederne $i$ sit Skrift fra 1856: Zur Schleswig-Holsteinischen Sache i m A ugust 1856 .

Af Behandlinger - mere eller mindre videnskabelige - af Begivenhederne foreligger der selvsagt saa mange, at det vil være ganske uoverkommeligt her at opregne dem. Jeg skal nøjes med at nævne af danske Skrifter $1 \mathrm{Bd}$. af $\mathrm{Neergaards:}$ Under Junigrund loven og af tyske den indgaaende og kritiske Undersogelse, som Dr. Herman n Hage n a h i 1916 offentliggjorde: Revolution und Legitimität in der Geschichte der Erhebung Schleswig-Hols teins. Untersuchungen zur Entstehungsgeschichte und zur Politik der Provisorischen Regierung (i Quellen und Forschungen zur Geschichte Schleswig-Holsteins. IV. 1916). Hagenahs Undersøgelse bygger ogsaa paa utrykt Materiale, og selv om den paa sine Steder har svært ved at gøre sig fri for det gængse slesvigholstenske Syn, at det absolut maa være Danmark, der angriber, betyder hans Forskning dog i det hele et betydeligt videnskabeligt Fremskridt.

At det var B es e ler, der bragte Lavinen i Skred, foreligger der nu mellem Kilderne ingen Uenighed om. De er enige i, at Beseler er den førende, og at det er med hans Ankomst fra Slesvig til Kiel om Eftermiddagen den 23, at Forhandlingerne om den provisoriske Regering tager deres Begyndelse. Og hvad der satte Beseler i Bevægelse, var Efterretningerne fra København om, hvad her var sket den 21. Marts. Som den 18. Marts i Rendsborg var Forudsætningen for den 21. i København, fremkaldte denne igen den 23, og 24. i Kiel. En malende Skildring af, hvordan det sidste Stød til det slesvig-holstenske Oprør kom, faar vi i det Brev, jeg næevnte, som Beseler 23. Marts 1873 skrev til sin Broder. Skildringen viduer om den feberagtige Ophidselse, den revolutionære Stemning, der herskede.

Brevet findes i Facsimile i Otto Beselers Bog, hvad der er heldigt nok, da Teksten ikke gengiver det korrekt. Det hedder i Brevet: 
"I denne samme Morgentime, i hvilken jeg skriver dette, stormede Jacobsen ind $\mathrm{i}$ Kontoret med de til Skriverne rettede Ord: har De Geværer? og derpaa ind i mit Arbejdsværelse med et Eksemplar i Haanden af den netop til Esselbachs Gæstgivergaard ankomne "Berlingske Tidende«, som udførligt berettede om Begivenhederne i København den 21. En Time senere sad jeg paa Vognen til Kiel. Fra Eckernførde sendte jeg Bud til Prinsen af Augustenborg, som man af Hensyn til Tropperne ikke kunde undvære. Fra Kiel til Fr. Reventlou, der ogsaa straks ankom. Da jeg havde underrettet ham om Stillingen og sluttet med de Ord: "aut nunc, aut nunquam " [nu eller aldrig], gav han mig med de Ord Haanden: "lad det saa gaa løs!" [denn man los]. I Morgen Kl. 10 vil jeg høre Rendsborgklokkernes glade Stormklang, der modtog os, da vi viste os paa den nedhejsede Eiderbro foran Jungfernstieg «.

Beselers sidste Ord sigter til Overrumplingen af Rendsborg om Formiddagen den 24. Marts. Den Jacobsen, der bringer Nyhederne til Beseler, er samme Mand, som senere blev slesvig-holstensk Krigsminister, og hans Opfordring til Skriverne om at kaste Penneskafterne og gribe Geværerne, maa altsaa have faldet ham naturlig. At det blev "Berlingske Tidende" og ikke de nationalliberales Organ »Fædrelandet», der satte Helstaten i Brand, er vel en Skæbnens Ironi.

I Kiel opsøgte Beseler naturligt nok det nedsatte Udvalgs tredie Medlem Advokat Bargum, og paa dennes Kontor begyndte Forhandlingerne om Aftenen. Inden jeg gaar over til disse, vil jeg dog først sige lidt om, hvad Prinsen a $\mathrm{N}$ ør havde at gøre ved disse Forhandlinger.

Prinsen havde $i$ et den 20. Marts dateret Brev til Kongen tilraadet denne at nedsætte et Administrations-Kollegium for Hertugdømmerne, bestaaende af ham selv som Statholder, kommanderende General og Kollegiets Præses samt iøvrigt af de tre Medlemmer af det af Stænderne nedsatte Lidvalg. Forinden Prinsen vilde overtage et saadant Hverv, skulde Kongen dog gaa ind paa de slesvig-holstenske Krav, bortset fra Punkterne om Slesvigs Optagelse $i$ det tyske Forbund og Folkevæbning. Herved mente Prinsen at kunne redde Hertugdommerne for 
Kongen og bidrage ikke lidet til at sikre ham hans danske Trone. At Kongen skulde gaa ind paa disse Forslag, ventede Prinsen efter sin egen Udtalelse, som man dog maaske ikke skal stole helt paa, nu ikke.

Om Begivenhederue den 23. inden Ankomsten til Kiel fortæller Prinsen i sine Optegnelser for sit Vedkommende følgende: Om Morgenen den 23. sendte han med ridende Bud et Brev til Samwer i Kiel og bad denne give sig Efterretninger om, hvordan den slesvig-holstenske Deputation var blevet modtaget i København, og hvad der iøvrigt var sket her. Kl. 4 Eftm. modtog han Brev fra Samwer, hvori der var Tale om Dannelsen af en provisorisk Regering, og efter Læsningen af dette vil han smilende have sagt: Det er dog nogle rigtige Vigtigpetere, disse Kielere! Nu vil de lave en provisorisk Regering og tror allerede, at den danske Hær er i Eckernførde. Før han havde spist, fik han et fra Eckernforde pr. Stafet afsendt Brev, hvori det hidtidige Ministeriums Afgang meddeltes, medens Lehmann, Hvidt og Tscherning nævntes som nye Ministre. Han gav da straks Ordre til at spænde for Vognen og meddelte sin Hustru, at han maatte til Kiel: han maatte se til, at man der ikke lavede Taabeligheder. Haandtasken blev pakket, og, skriver han, for let Tilfældes Skyld, at Kongens Antagelse af hans Forslag maatte have naaet ham i Kiel, tog han ogsaa sin gamle Militærfrakke og Sabel med. Han lægger $i$ sin Skildring megen Vxgt paa at vise, at han kun tænkte paa at blive borte en Dags Tid. Næppe var han taget af Sted, før der kom Bud fra Hertugen af Glücksborg om, at han for Himlens Skyld maatte tage til Kiel. hvor alle besindige Folk ventede ham med Længsel, og en Mils Vej senere kom et ridende Bud sprængende frem til Vognen med et nyt Brev fra Samwer. Prinsen raabte: "Hier bin ich selber«, rid tilbage og meddel Samwer, at jeg allerede er undervejs. Ankommen til Kiel opsøgte han Bargum og fik at vide, at Beseler allerede var kommet, og at der var sendt Ilbud efter Reventlou.

Naar jeg nu vil hævde, at Problemet i denne Skildring stikker i det Spørgsmaal, hvorfor Prins Frederik af Nør - i 1846 afskediget fra Stillingen som Statholder og kommanderen- 
de General i Hertugdømmerne - tog sin gamle Militarfrakke med paa Rejsen til Kiel, saa skal dette ikke opfattes som en spogefuld Bemærkning. Det falder nemlig meget vanskeligt at tro paa den Forklaring, som han selv giver. Han har tidligere fortalt, at han Torsdag [den 23.] Formiddag kunde vente Kongens Svar paa sit Forslag, saafremt et Dampskib havde bragt Svaret direkte til Nør. Han var imidlertid overtydet om, at man i København ikke vilde høre paa Fornuft og rettede derfor ikke engang en Kikkert mod Havet for at opdage et Dampskibs rygende Skorsten. Samme Eftermiddag fik han Brevet om Begivenhederne $\mathrm{i}$ København, hvorom han siger, at de betød, at Angrebet paa Hertugdømmerne og deres Adskillelse var den danske Regerings udtalte Program. Var der da herefter nogen som helst Mulighed for, at Kongen kunde svare Ja til hans Krav, og naar han om Formiddagen ikke engang gad rette Kikkerten mod Havet, skulde han da om Aftenen for en ikke eksisterende Muligheds Skyld slæbe Militærfrakken med til Kiel?

Der er desuden i Prinsens Skildring en anden Omstændighed, der gør én mistænksom overfor den, det er den Vægt, han som næunt lægger paa at vise, at han kun vilde blive borte $\mathrm{i}$ kort Tid: han lod sine Papirer og Sager som sadvanlig ligge paa sin Skrivepult og udstedte ingen særlige Ordrer til sine Folk! Den naturlige Forklaring herpaa er dog vistnok ien, at det gjaldt for ham hurtigst muligt at komme til Kiel, at Revolutionsfeberen havde grebet Tag i ham som forhen i Beseler, der en Time efter, at Jacobsen var stormet ind med "Berlingske«, sad i sin Vogn paa Vej til Kiel.

Men hvorfor skulde da Militærfrakken og Sabelen med til Kiel? Skulde der alligevel være noget om gamle Wegeners Paastande om et augustenborgsk Oprør og om en eksisterende Sammensværgelse? Det er Paastande, som Droysen i sit Afsnit af sin og Samwers Bog benægter paa det bestemteste: "V'i har", skriver han, "staaet Begivenhederne nær nok til at kunne forsikre med historisk Samvittighedsfuldhed, at der heller ikke mellem dem, som den forste Dag fandt forenet i Spidsen for Hertugdømmerne, var aftalt det ringeste. Med Beseler stod 
F'rinsen siden Slesvig-Valget i 1847 paa en meget spændt Fod, og mellem Grev Reventlou og Beseler havde der hidtil slet ingen Forbindelse bestaaet«.

I min Omtale af Prinsen af Nørs Optegnelser om den 23. Marts har jeg hidtil holdt mig til de kritiske Bemærkninger, som det forekommer mig, at selve Kilden giver Anledning til. Der foreligger imidlertid ogsaa andre Vidnesbyrd, der viser, at hans Fremstilling - trods Bedyrelsen i Forordet af hans Sandhedskærlighed - sikkert ikke kan være korrekt.

Droysen aftrykker et Brev eller et Stykke af et Brev som Prinsen den 23. efter Modtagelsen af Brevet fra Eckernforde skrev til sin Broder, Hertugen, i Berlin. Brevet er dateret Nør, altsaa skrevet, medens Hestene spændtes for Vognen. Det hedder i Brevet: "Lige nu indløber den Efterretning fra Kiel, at en Opstand har tvunget Kongen til at afskedige Ministeriet. Hvidt og Lehmann skal danne det nye Ministerium, Dampskibet fra København, der skulde komme i Dag, er hidtil udeblevet, sandsynligvis for at hidføre en hel Dampflotille med Tropper, Generalkommandoen fra Slesvig er, efter hvad der siges, marcheret fra Slesvig mod Rendsborg med alle Tropperne. - Under disse Omstændigheder er Kongen ikke mere en iri Mand". - I Prinsens sidste Ord møder vi Begrebet om "den ufri Konge«, "et genkommende Revolutionsmotiv« - for at citere et Foredrag, der sidste Sommer blev holdt paa Nordens aldste Universitet. Men maa det nu ikke forekomme ganske usandsynligt, at Prinsen, netop som han skriver dette Brev, har tænkt paa at tage Militærfrakken med til Kiel for det Tilfældes Skyld, at "den ufri Konge« skulde have accepteret hans Forslag? Brevets Udtryk lægger unægtelig en ganske anden Fortolkning snublende nær.

Naar Droysen siger, at der bestod et spændt Forhold mellem Prinsen og Beseler, saa er det i hvert Fald korrekt, hvis man retter Udtalelsen til: havde bestaaet. Af Beselers tidligere nævnte Brev fra 1873 ses det nemlig, at let var Beseier, der fra Eckernførde stævnede Prinsen til Møde i Kiel. Prinsen fulgte, som vi har set, sporenstregs Opfordringen. Beselers Brev fortæller intet om Vanskeligheder ved at faa Prinsen til 
at deltage i Revolutionen, det er derimod over for Reventlou, lian udfolder sin Veltalenhed: saut nunc aut nunquam« og med det ønskede Resultat. Da Slutninger "e silentio" imidlertid som bekendt er meget farlige, skal jeg selvsagt ikke laegge nogen afgørende Vægt herpaa. Jeg vil dog samtidig fremhæve det ret mærkelige $i$, at Prinsen, der husker baade Brevene fra Samwer og fra Hertugen af Glücksborg, i sine Optegnelser har "glemt«, hvem det var, der sendte det afgørende Brev fra Eckernførde. Man kan ikke andet end gøre sig sine Tanker om, hvorfor han ikke vil ud med Beselers Navn. At hall faktisk skulde have glemt det, synes dog lidet troligt.

Da Samwer i 1878 nedskrev den anden Version af sin Beretning om Begivenhederne i 1848, havde han ikke længere de Hensyn at tage som omkring 1850. Prinsen af Nør var død, og det slesvig-holstenske Spørgsmaal var - efter Tysklands Mening - endelig afgjort. Samwer meddeler nu her, at den Opgave, som han efter Februarrevolutionen i Paris stillede sig, var at forberede Grev Reventlou og Prinsen af Nør paa sammen med Beseler at stille sig i Spidsen for Landet. Prinsen viste sig tilbøjelig hertil, medens Reventlou længe modstod Tanken om at gribe Regeringens Tøjler »uden og mod Landsherren«. «Jeg sagde«, skriver Samwer, «forud til dem begge, at der ikke vilue være andet at gøre, thi paa et givet Tidspunkt vilde Danskerue kaste sig over Slesvig«. Videre beretter Samwer, at han den 23. med Tanke paa en eventuel dansk Troppeforsendelse til Fckernførde skrev til Prinsen for at bede ham om at virke for at allarmere Vejen fra Eckernførde til Rendsborg, og at Prinsen uclførte dette paa meget fyldestgørende Vis. Dette Hverv ira. Prinsen dog altsaa faaet Tid til at udføre, og mon det ikke ogsaa $\mathrm{i}$ den Stund har forekommet ham ulige vigtigere, end om der laa nogle Papirer og flød paa hans Skrivepult? I Revolutionstider maa den Mulighed vel bestaa, at selv det korrekteste Ordensmenneske kan lade en Papirlap ligge.

Hvad Samwer meddeler i 1878 om Prinsens Villighed til at indtræde $i$ en provisorisk Regering sammen med Beseler og Reventlou, bekræftes desuden af det Brev, som Prinsen den 23. om Morgenen skrev til Samwer. Dette Brev havde nemlig al- 
deles ikke den uskyldige Karakter: en Anmodning om Nyheder fra København, som Prinsen i sine Optegnelser vil tillægge det. Brevet er desværre ikke trykt, men Dr. Hagenah har haft Adgang til at benytte det og refererer det $i$ sin førnævnte Afhandling. Efter Hagenahs Referat skal Prinsen i Brevet have søgt at bortrydde Reventlous Betænkeligheder mod en provisorisk Regering og have udtalt, at den nuværende Regering, hvis den ikke opfyldte Kravene fra Rendsborg, ikke med Rette bar en Regerings Navn, og at den saa enten var utilregnelig eller fjendtlig. Det faar staa hen, med hvilke Udtryk man vil betegne Droysens Paastand om, at der før den 24. Marts aldeles intet var aftalt mellem de Mænd, der da dannede den provisoriske Regering, og hans Fremhævelse af, at Beseler og Prinsen af Nor stod paa en meget spændt Fod. Saa meget er $i$ hvert Fald klart, at hvor stærkt han end paaberaaber sig sin "historiske Samvittighedsfuldhed" eller glæder sig til de "Løgne", hvormed man fra dansk Side vilde imødegaa hans Fremstilling : hele Sandheden giver han os ikke! Da Prinsen af Nør efterkom Beselers Opfordring fra Eckernførde, da han jog imod Kiel medtagende sin gamle Militærfrakke og Sabel, da var det for at stille sig i Spidsen for den slesvig-holstenske Rivolution!

Efter at Reventlou ved sit Komme til Kiel var blevet revet med af Beselers Veltalenhed og gav sig Revolutionen i Vold med Ordene: lad det saa gaa løs, kunde man vel have tænkt sig, at der ikke længere var Hindringer i Vejen for Dannelsen af en provisorisk Regering, bestaaende af de tre Ldvalgsmedlemmer samt Prinsen, den sidste jo efter Beselers Udsagn nødvendig af Hensyn til Tropperne. Saa glat skulde det dog ikke gaa. Paa Bargums Forretningskontor debatterede de nævite 4 Herrer, og her gik Mænd som Professorerne Falck og Droysen, Hertugen af Glücksborg og Samwer ud og ind. Men der havde samtidig dannet sig et nyt Revolutionscentru m et andet Sted i Byen, nemlig paa Raadhuset. Her santledes de mere radikale og demokratiske Kredse, Folk, der som Førere havde Olshausen og Advokat Claussen, som jo imidler- 
tid var borte paa Sendefærden i København. Samwer karakteriserer ganske træffende disse Kredse ved at spotte over, at de ikke vilde tage Ordet "Rathhaus" $\mathrm{i}$ deres Mund, men kaldte ret "Stadthaus" i Lighed med det franske Hôtel de ville.

Da Droysen i 1850 skrev sit Tendensskrift - i en Tid, hvor Revolutionen ikke mere var i høj Kurs - gjaldt det for ham at vise, at Begivenheden i Kiel ikke var "noget Oprør eller Revolution, ingen Gadekonspiration eller Klubintrige«. Det gjaldt ligeledes for ham om at fastslaa, at der hele Aftenen og Natten igennem ikke forekom nogen som helst Rolighedsforstyrrelse eller Tumult i Byen. Hvad der skete i Nattens Løb, var efter hans Skildring følgende: Prinsen, Beseler og Reventlou, supplerende sig med Købmand M. T. Schmidt i Kiel og Advokat Bremer fra Flensborg, besluttede sig til provisorisk at overtage Hertugdømmernes Regering. Omkring Midnat affattede de Proklamationen og begav sig med denne til Raadhuset, hvor der var samlet omkring 30 Borgere og Indbyggere sammen med Stadsyndicus. Disse meddelte de deres Beslutning og Proklamation og spurgte dem, om de paa dette Grundlag var rede til med Gods og Blod at bistaa den provisoriske Regering i dens tunge Opgave. "Tilslutningen fulgte enstemmigt«. Om Morgenen Kl. 6 fandt saa den provisoriske Regerings højtidelige Proklamation Sted.

Denne Droysens Skildring er nu i høj Grad fortegnet, hvad man kan se af samtlige andre Kilder - ogsaa af Prinsens Optegnelser, der for at tækkes Fyrstehusene lægger Vægt paa at berette, hvor arrogant og afvisende han optraadte over for Radikalerne paa »Hôtel de ville«, og af Samwers Beretninger. Den sidste geraadede for Resten i skarp Ordstrid med en af Radikalerne og trak blank. Men de bedste Kilder til Belysning af den Indflydelse, som de radikale fik paa den provisoriske Regerings Dannelse, er selvfølgelig Beretningerne fra radikal Side - Otto Focks Erinnerungen og den samtidige Skildring i Correspondenz-Blatt, der i Olshausens Fraværelse redigeredes af Advokat Hedde, der var blandt Folkene paa Raadhuset. I Altonaer Mercur hedder det $i$ en Korrespondance Kl. 11 Aften fra Kiel: Borgerforeningens Bestyrelse og mange Borgere i 
Byen, der er kommet sammen paa Raadhuset, har sat sig i Forbindelse med den af Stænderne nedsatte Komité, med hvilken Prinsen forhandler. Correspondenz-Blatt omtaler Folkene paa Haadhuset som en Række frihedselskende Mænd og fortæller, hvordan de kræver Indflydelse paa Regeringens Sammensætning. Resultatet af Forhandlingerne blev, at Bargum erstattedes med M. T. Schmidt, der skal have holdt til paa Raadhuset, og at Bremer i Flensborg af Hensyn til Stemningen i Nordslesvig skulde opfordres til at indtræde.

De mange Problemer, der knytter sig til Forhandlingernes Forløb i det enkelte, maa jeg her lade ligge. Jeg maa nøjes med at belyse, hvad de forskellige Kilder har om, hvordan den endelige Enighed mellem Mændene fra Bargums Kontor og dem fra Raadhuset tilvejebragtes. Ifølge de samtidige Kilder (Correspondenz-Blatt og Altonaer Mercur) var Kl. omkring $1 \mathrm{om}$ Natten, da den provisoriske Regerings \& Medlemmer indfandt sig paa Raadhuset, og Beseler oplæste Proklamationen, for at de der forsamlede kunde billige den. Proklamationens Form stødte imidlertid paa stærk Modstand - heri er Kilderne (bortset fra Droysen) ganske enige, selv om de varierer Udtrykkene noget. Imod den talte "flere«, siges der, efter Focks Oplysning saaledes Hedde. Modstanderne af Proklamationen savnede $i$ denne, meddeler Correspondenz-Blatt, den udtrykkelige Anerkendelse af Tidens Krav: Presse- og Forsamlingsfrihed, Nævningedomstole, Folkevæbning med Valg af alle Officerer og en Valglov paa friest mulig Basis.

Det blev nu ikke Beseler, men Grev Reventlou, der greb Ordet og efter Samwers Udtryk holdt »en storslaaet Tale«, der tilvejebragte Enighed mellem de to Lejre. Af denne Tale foreligger der i hvert Fald 4 forskellige Referater, de to stammende fra radikale Kilder: Correspondenz-Blatt og Fock, de to fra konscrvativ-augustenborgsk Side: Prinsen af Nors Erindringer og Samwers 1. Version. Alle disse Kilder er Førstehaandskilder.

Hvad Grev Reventlou har sagt i Enkeltheder, vil formentlig ingen Sinde blive oplyst. Men det afgørende Punkt er, hvad han har svaret paa de demokratiske Kredses Fordringer. Efter Prinsens Referat gik Talen ud paa en bestemt, nærmest endda 
lidt haanlig Afvisning af disse, og Reventlou skal have sluttet med, at saafremt der ændredes en Tøddel i Proklamationen, vilde hverken han eller Prinsen deltage i Bevægelsen. Samtlige tilstedeværende skulde erklære sig enige i Proklamationen og give ham Haanden derpaa.

At Reventlous Tale kan have haft denne Form, maa imidlertid være udelukket. Hvordan skulde en saadan Tale kunne begejstre Demokraterne? Man kan ogsaa med Grund sætte et Sporgsmaalstegn ved, at Reventlou skal have sagt, at Prinsen ikke vilde deltage i Bevægelsen, saafremt Proklamationen ændredes. Demokraterne onskede Prinsen med hans arrogante Væsen hen, hvor Peberet gror, og de var meget imod hans Optagelse i Regeringen.

I Samwers Referat har Talen heller ikke den afvisende Karakter som hos Prinsen. Det hedder her: "Ikke deres Løfter, men deres Personlighed maa være en Borgen for, at de i indre Spørgsmaal vilde opfylde Folkets virkelige Ønsker. Hvilke disse var, tilkom det alene de lovlige Organer at afgøre«. Maaske vilde Landsherren igen snart kunne overtage Regeringens Tøjler, men trak dette Tidspunkt ud, maatte de ogsaa handle $i$ de indre Spørgsmaal. Han kunde imidlertid ikke give andet bindende Lofte end det, at Regeringen uopholdelig vilde træffe Foranstaltninger til Landets Forsvar. Han endte med at appellere til Enigheden og kræve alles ubetingede Tilslutning til Proklamationen.

I Modsatning til de konservative Kilder er de to demokratiske enige deri, at Reventlou i Talen skal have billiget de demokratiske Krav. Fock beretter, at han vel udtalte, at Regeringen maatte handle $i$ »den ufri Konges" Navn, men at han betegnede Opfyldelsen af de demokratiske Krav som selvfølgelige i en Tid som den nærværende, og at han vilde indestaa herfor. Tillige fremhævede han, at Bevægelsen selvsagt maatte foregaa i den snævreste Tilslutning til den store samtidige Bevægelse $i$ hele det tyske Fædreland.

For Correspondenz-Blatt maatte der aabenbart ligge en særlig Vægt paa at vise, at Kredsen af frihedselskende Mænd paa Raadhuset ikke var gaaet tomhændet ud af den bevægede Nats 
Forhandlinger. Af Reventlous Tale anfører det heller kun, hvad det opfatter som et bestemt Tilsagn til demokratisk Side: sat den provisoriske Regering var overbevist om, at blot i Opfyldelsen af disse Krav [de demokratiske] kunde Folkets Kraft og Fremtid bestaa, og at den selv for sit Vedkommende vilde gøre alt for denne Opfyldelse«. Correspondenz-Blatt skriver videre, at "en saadan lige saa bestemt som kraftig afgiven Erklæring maatte, idet den tilfredsstillede Folkets ædleste og bedste Ønsker, finde almindelig Tilslutning «.

Naar man tager i Betænkning, at der efter Reventlous Tale fulgte et enstemmigt Ja fra Folkene paa Raadhuset, og at de udbrød i Leveraab for den provisoriske Regerings Mænd, tør det formentlig hævdes, at Correspondenz-Blatt i sit Referat af Talen med Hensyn til dette Punkt maa have større Ret end de konservative Referater. Og til yderligere Bekræftelse herpaa skal anføres, at hans Tilsagn i Virkeligheden svarede godt til den Passus i Proklamationen: "Vi vil med al Kraft slutte os til Tysklands Enheds- og Frihedsbestræbelser«. Det er en Passus, om hvilken Beseler skal have sagt, at den nødvendig maatte optages af Hensyn til Raadhusfolkene, og Tysklands daværende Frihedsbestræbelser de gjaldt jo netop Opfyldelsen af de omtalte demokratiske Krav. Reventlou gik i sin Tale for saa vidt ikke med til mere, end han i Forvejen ved Proklamationens Udformning havde billiget. Tyske Historikere har debatteret, om det var Beseler og Reventlou eller Droysen, der skrev Proklamationen. Et i og for sig lidt mærkeligt Spørgsmaal, for selv om Droysen førte Proklamationen i Pennen, maa dens Indhold selvfølgelig være formet gennem Forhandling mellem de to Leclere Beseler og Reventlou; dens Form blev et Kompromis mellem den enes mere revolutionære og den andens mere fyrstetro Sindelag. Blandt Demokraterne har man sikkert ikke næret Mistillid til, at Beseler vilde komme dem i Møde. Først da Reventlou greb Ordet og med Varme og Bestemthed traadte $i$ Skranken ogsaa for de tyske Enheds- og Frihedskrav, først da forenedes de hidtil adskilte Lejre. I den enstemmige Tilslutning, som hans Opfordring til at bistaa den provisoriske Regering med Gods og Blod fik, klang som en Gentagelse af de Ord, 
han selv havile udtalt om Aftenen efter Beselers Tale: Lad det saa gaa los! ("dem man losu).

\section{Eilder.}

[Kialer] Correspondenz-13latt. (Extra-Blat1). 24/3 1848 . Altonarer Mereur. Nr. $22.24 / 31848$.

Beilage zum dixtlablatt des Itzohom Wochenblatts. 2h/3 18.tx. (Miltags 12 I’hr).

Droysen og Samwer: Die Herzogthïmor Schleswig-llolstein und das Königroich Dänemark. Aktrmmässige (ieschichte der dänischin

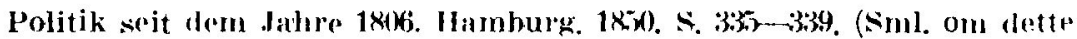
Skrift. Johann Gustav Jroysens Briefwechsel, herausergeben v. IRudolf llübner. I. 19\%9g. S. J\&6 ff).

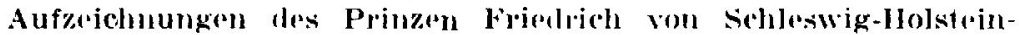

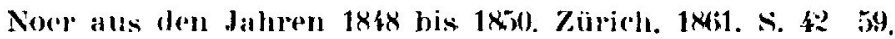

(otto Fock: Schleswig-Ilolsteinische binnelungen besonders aus den Jahren 18ix-16i1. Leipeig. 1863. s. 5i-79.

Dir Erhebung Schleswig-llolsteins vom :4. Marz 1848. Aufzoid/nungen aus dern Nachlass soll Karl Frierleich Ioucian samwer. Wieshaden 1898.

Wilhelm llatwig Beseler. Lin lebenshild soines Vaters gezeichset von otto Beseler. Braunschweig. 1914. S. ig f. (Sml. Wilhelm Bewler: Zur Schloswig-llolsteinischen Sache im August 18:56. J3raunachweig. 18.x); s. 66).

\section{Behandlinger.}

Af clisse anfores kun:

X. Veergaarl: Under Junigrundloven. I. 1892. S. 172-176.

IIermann Hagenah: Pevolution und Legitimitit in der Geschichtr der Erhobung Schleswig-Holsteins. Untersuchungen zur Fintstehungsgeschichte und zur Politik der Provisorischen Rogierung. S. 93-118 (i Quellen und Forschungen zur Geschichte Schlesvig-Holsteins. Vierter Band. 1916). (Benytter utrykt Materiale og har for sia vidt hildevirardi).

Samme: Zur Geschichte des 24. März 1848 (i Die Hoimat. 1923. S. 42-46). 